\title{
Effects of Replacing Roughage with Soy Hulls on Feeding Behavior and Milk Production of Dairy Cows Under Hot Weather Conditions
}

\author{
I. Halachmi, ${ }^{1}$ E. Maltz, ${ }^{1}$ N. Livshin, ${ }^{1}$ A. Antler, ${ }^{1}$ D. Ben-Ghedalia, ${ }^{2}$ and J. Miron ${ }^{2}$ \\ ${ }^{1}$ Institute of Agricultural Engineering and ${ }^{2}$ Institute of Animal Science, \\ Agricultural Research Organization, The Volcani Center, Bet Dagan 50250, Israel
}

\begin{abstract}
Two total mixed rations (TMR) containing different proportions of roughage neutral detergent fiber (NDF) were fed to lactating cows under Israeli summer conditions, and the effects on feeding behavior and milk production were measured. Forty-two lactating cows were divided into 2 groups fed ad libitum a TMR containing either 18\% NDF of roughage origin (control group) or only $12 \%$ roughage NDF, in which the corn silage component ( $16.5 \%$ of dry matter [DM]) was replaced with soy hulls (experiment group). This and additional adjustments in TMR were reflected in higher net energy for lactation and in vitro digestibility of the experimental TMR. Cow behavior was investigated at the feeding lane during June 2001; about 11,000 cow visits were analyzed. Feed intake per meal and average meal duration were significantly higher in the experiment group (1.51 kg of DM per meal and $12.1 \mathrm{~min}$ per meal, respectively) as compared with the control group $(1.22 \mathrm{~kg}$ of DM per meal and 9.47 min per meal, respectively). However, number of meals per day recorded in the feeding lane was significantly higher in the control group (21.0 vs. 16.6 meals/d per cow). Distribution of meals and feed intake along the day depended more on management practices, such as milking and feed dispensing times, than on feed composition or weather conditions. These differences between groups were expressed in similar daily eating duration ( 200 min), and because the rate of feed consumption was similar for both treatments ( 127 g DM/min), the daily average DM intake was also similar (25.0 to $25.7 \mathrm{~kg}$ ). However, NDF intake was higher in the experiment group. Consequently, the average milk yield was higher in the experimental group, and production of milk fat, $4 \%$ fat-corrected milk, and economically corrected milk were significantly higher in the experiment group than in the control group. Data imply that the experimental TMR containing only $12 \% \mathrm{NDF}$ of roughage origin is more suit-
\end{abstract}

Received July 17, 2003.

Accepted February 26, 2004.

Corresponding author: I. Halachmi; e-mail: halachmi@volcani. agri.gov.il. able for cows under hot climate conditions compared with the control TMR.

(Key words: dairy cow, feeding behavior, roughage neutral detergent fiber level, corn silage vs. soy hulls)

Abbreviation key: $\mathbf{C S}=$ corn silage, $\mathbf{E C M}=$ economically calculated milk, $\mathbf{S H}=$ soy hulls .

\section{INTRODUCTION}

Under hot weather conditions, lactating cows need to consume more energy to supply their increased maintenance requirements, which are growing by 7 to $25 \%$ (NRC, 2001). However, voluntary DMI can be decreased by $6 \%$ with an increase in ambient temperature that is $>30^{\circ} \mathrm{C}$ (Eastridge et al., 1998). Thus, under hot weather conditions, the NRC (2001) recommendation of 18 to $19 \%$ roughage NDF in TMR might be too high and problematic in the supply of energy requirements to high-producing cows. Increasing energy content by supplying more starchy grains to the diet might reduce dietary NDF content and utilization for milk fat production (NRC, 2001).

An approach to overcome the problem of feeding lactating cows under hot weather conditions is to increase energy consumption by replacing the TMR roughage component with readily digestible NDF-rich by-products such as soy hulls (SH). Soy hulls contain a readily digestible NDF fraction (Miron et al., 2001) and were proposed as a replacement for various forages in the rations of lactating cows (Weidner and Grant, 1994; Slater et al., 2000; Ipharraguerre and Clark, 2003). In some previous studies, replacing roughage with $\mathrm{SH}$ increased DMI (Weidner and Grant, 1994; Slater et al., 2000), whereas, in other studies, it reduced or did not affect DMI (Firkins and Eastridge, 1992; Cunningham et al., 1993; Mowrey et al., 1999). This conflict between studies and the lack of knowledge about the effect on cow behavior and performance under hot weather conditions (Ipharraguerre and Clark, 2003) motivated the present study.

The hypothesis in this study is that, under hot weather conditions of the Israeli summer, feeding lactating cows a more digestible NDF of non-roughage 
Table 1. Ingredient and chemical composition of the 2 TMR.

\begin{tabular}{|c|c|c|c|c|}
\hline & Experimental $^{1}$ & Control $^{1}$ & SEM & $P$ \\
\hline Ingredient & \multicolumn{2}{|c|}{$-(\%$ of TMR DM $)-$} & & \\
\hline Concentrate mixture $^{2}$ & 39.4 & 39.4 & & \\
\hline Mineral and vitamin mixture ${ }^{3}$ & 3.20 & 3.20 & & \\
\hline Whole cottonseeds & 13.5 & 13.5 & & \\
\hline Sunflower meal (solvent-extracted) & 5.0 & 7.85 & & \\
\hline Soybean hulls & 16.5 & 0 & & \\
\hline Corn silage & 0 & 16.5 & & \\
\hline Pea hay & 4.4 & 4.4 & & \\
\hline Coarse oat hay & 7.9 & 3.95 & & \\
\hline Wheat silage & 10.1 & 11.2 & & \\
\hline \multicolumn{5}{|l|}{ Chemical composition } \\
\hline $\mathrm{DM}$ & 62.5 & 62.5 & 0.12 & 0.50 \\
\hline $\mathrm{OM}$ & 92.1 & 91.7 & 0.21 & 0.43 \\
\hline $\mathrm{CP}$ & 16.8 & 16.8 & 0.32 & 0.60 \\
\hline Fat (ether extract) & 5.11 & 5.20 & 0.08 & 0.20 \\
\hline $\mathrm{NDF}$ & $38.9^{\mathrm{a}}$ & $35.9^{\mathrm{b}}$ & 0.46 & 0.03 \\
\hline Roughage NDF & $12.0^{\mathrm{a}}$ & $18.0^{\mathrm{b}}$ & 0.22 & 0.01 \\
\hline Density of TMR (kg/L) & 0.48 & 0.48 & 0.02 & 0.64 \\
\hline Extent of in vitro OM digestibility $(\%)$ & $77.7^{\mathrm{a}}$ & $73.0^{\mathrm{b}}$ & 0.39 & 0.01 \\
\hline Extent of in vitro NDF digestibility (\%) & $59.8^{\mathrm{a}}$ & $44.4^{\mathrm{b}}$ & 1.49 & 0.04 \\
\hline Calculated $\mathrm{NE}_{\mathrm{L}}(\mathrm{Mcal} / \mathrm{kg}$ of $\mathrm{DM})$ & 1.73 & 1.66 & & \\
\hline \multicolumn{5}{|c|}{${ }^{\mathrm{a}, \mathrm{b}}$ Means in the same row following by different superscripts differ at $P<0.05$} \\
\hline \multicolumn{5}{|c|}{$\begin{array}{l}{ }^{2} \text { Concentrate mix contained (\% of DM): ground corn grain, } 41.2 \text {; rolled barley grain, } 33.1 \text {; soybean meal } \\
\text { (solvent extract), } 12.3 \text {; canola meal, } 6.7 \text {; corn gluten feed, } 6.1 \text {; and soybean oil, } 0.6 \text {. }\end{array}$} \\
\hline \multicolumn{5}{|c|}{$\begin{array}{l}{ }^{3} \text { Mineral and vitamins mix contained ( } \mathrm{g} / \mathrm{kg} \mathrm{DM} \text { ): ammonium sulfate, } 31.2 \text {; calcium chloride, } 500 \text {; dicalcium } \\
\text { phosphate, } 62.5 \text {; magnesium oxide, } 62.5 \text {; sodium bicarbonate, } 312.5 \text {; and trace minerals + vitamin mix, } 31.3 \text {. }\end{array}$} \\
\hline
\end{tabular}

origin as forage replacer might improve energy and NDF consumption and improve $4 \%$ FCM production. This hypothesis is based on a previous performance study operated under moderated weather conditions, which showed that SH successfully replaced corn silage (CS) and reduced forage NDF content of the TMR from 18 to $12 \%$ (Miron et al., 2003). However, intake behavior of milking cows under hot weather conditions was not measured in the previous study.

The objective of this study was to analyze the effects on feeding behavior and milking performance of cows under hot weather conditions when roughage NDF was replaced by $\mathrm{SH}$ and the roughage NDF component of the TMR was reduced from 18 to $12 \%$.

\section{MATERIALS AND METHODS}

\section{Cows, Diets, and Sampling Procedures}

Forty-two lactating multiparous Holstein cows (average $=2.9$ lactations) were fed the control TMR described subsequently (Table 1) for $6 \mathrm{wk}$ of a pre-experiment period. At the end of this standardization period, cows were divided into 2 groups, each of 21 animals, similar in average (means $\pm \mathrm{SE}$ ) stage of lactation (125 \pm 5.3 DIM), daily milk yield $(39.0 \pm 0.75 \mathrm{~kg})$, and BW (583 \pm $8.2 \mathrm{~kg}$ ). During the basal period and additional $6 \mathrm{wk}$ of the experiment, all cows were housed in the Agricul- tural Research Organization research farm in one shaded corral yard. They had free access to water and were milked 3 times daily at 0600, 1400, and $2100 \mathrm{~h}$. A TMR was served once daily at 1000 to $1100 \mathrm{~h}$ for ad libitum intake, allowing for 5 to $10 \%$ orts. All cows received each day at 1200 and $1600 \mathrm{~h}$, cooling showers in the milking yard. A computerized monitoring system was equipped for electronic identification of each cow approaching the fodder as well as automatic control and recording of their entry into the feed stalls. Each forage feeder was equipped with an electronic antenna mounted on weighing balances to facilitate monitoring and analysis of the voluntary feed intake and behavior of each animal in the group. The DMI and meal duration were measured for each meal. The system design was described previously by Halachmi et al. (1998). To overcome possible effects of the location of a feeding position, the positions were arranged in multiples of $6: 2 \mathrm{TMR}$ were assigned to 3.5 groups of 6 adjacent feeding positions, and each group of 6 control TMR positions was followed by a group of 6 experimental TMR positions. All cows, experimental and control, were kept together.

During the 6 wk of the experiment, the control group continued with the basal TMR containing $16.5 \%$ CS and a total of $18 \%$ NDF of roughage origin, whereas the experimental group received during this period a similar TMR in which the CS component was replaced 
with $\mathrm{SH}$ so that the roughage NDF content was reduced to $12 \%$. Detailed TMR compositions are shown in Table 1. The level of coarse oat hay was slightly higher in the experimental TMR than in the control TMR (7.9\% vs. $3.95 \%$ ) to compensate for the lower content of roughage $\mathrm{NDF}$ and to obtain similar fiber effectiveness in both TMR, as measured by TMR density, which was adjusted to $0.48 \mathrm{~kg} / \mathrm{L}$ in both rations. Protein sources were slightly modified, and water was added to the experimental TMR to obtain similar CP and DM content in both TMR.

Cow feeding behavior and feed intake were monitored after 2 wk of adaptation to the experimental TMR during the last $4 \mathrm{wk}$ of the experimental period (June 1 to $28,2001)$, when the average ambient temperatures were around $30 / 20^{\circ} \mathrm{C}$ day/night. The TMR were sampled daily and pooled on a weekly basis to produce composite samples for each dietary treatment. Dry matter intake was determined by oven-drying a portion of the weekly TMR samples at $105^{\circ} \mathrm{C}$ for $24 \mathrm{~h}$. The weekly TMR samples were oven-dried at $60^{\circ} \mathrm{C}$ for $48 \mathrm{~h}$, ground through a 1-mm screen, and used for in vitro digestibility evaluation and chemical analyses. Daily milk yield during the $4 \mathrm{wk}$ of the experiment was recorded by an automatic milk meter (SAE Afikim, Israel). Milk samples were collected during 3 successive milkings on each Wednesday during the experimental period. Every set of fresh milk samples for each cow was stored at $4^{\circ} \mathrm{C}$ with preservative peals until analyzed by infrared for content of fat, protein, and lactose at the Dairy Milk Association Laboratory (Caesarea, Israel) by means of a Milkoscan 4000 instrument (Foss Electric, Hillerød, Denmark).

\section{Chemical Analyses}

Samples of dried TMR were collected weekly and assayed in triplicate for DM, ether extract, and OM (AOAC, 1984). Crude protein was determined by the Kjeldahl method (AOAC, 1984), and the NDF content was determined in duplicate in TMR samples, SH, CS samples, and the in vitro residues according to Van Soest et al. (1991) by means of the $\alpha$-amylase procedure, with the Ancom apparatus used for extraction and filtering.

In the present study, TMR density was used as the basis for rough estimation of the effective fiber content of the wet feed and was measured as described previously (Miron et al., 2003). The in vitro OM and NDF digestibilities were analyzed in triplicate by applying $48 \mathrm{~h}$ of incubation with rumen fluid followed by a 48$\mathrm{h}$ incubation with pepsin- $\mathrm{HCl}$ according to the 2-stage fermentation technique of Tilley and Terry (1963). Composited samples of ruminal inoculum were obtained from 4 cows fed the experimental TMR and 4 cows fed the control TMR.

\section{Calculations and Statistical Methods}

The yield of 4\% FCM and the payment equation (economically calculated milk [ECM]) were calculated according to the equation used by the Israeli Dairy Milk Association:

$4 \% \mathrm{FCM}(\mathrm{kg})=0.4 \times$ milk $(\mathrm{kg})+15.0 \times$ milk fat $(\mathrm{kg})$

$$
\begin{gathered}
\mathrm{ECM}(\mathrm{kg})=9.436 \times \text { milk fat }(\mathrm{kg}) \\
+22.018 \times \text { milk protein }(\mathrm{kg}) .
\end{gathered}
$$

Differences between the 2 TMR, with respect to composition and in vitro digestibility, were tested for significance by a standard $t$-test comparison (Little and Hills, 1978).

Data of feeding behavior of the individual cows including number of meals per day, meal duration, daily feeding duration, extent and rate of feed consumption per meal, and daily DM and NDF intakes as well as performance data including milk yield and composition and BW were reduced to means per cow per day in the $4 \mathrm{wk}$ of experimental period after $14 \mathrm{~d}$ of adaptation to the diets. These data were analyzed by ANOVA using the GLM procedure of SAS (SAS, 1996).

\section{RESULTS AND DISCUSSION}

\section{TMR Composition and Digestibility}

Both TMR contained high levels of total NDF (38.9 and 35.9\%; Table 1); however, in the experimental ration, $69 \%$ of the NDF was of non-roughage origin, whereas in the control TMR, about one-half of the NDF originated from roughage. This difference in dietary NDF content and origin exerted not only quantitative but also qualitative differences between the 2 diets, as the extent of NDF in vitro digestibility of $\mathrm{SH}$ is significantly higher than that of CS (83\% vs. 56\%; Miron et al., 2003). This difference was reflected by higher calculated content of $\mathrm{NE}_{\mathrm{L}}$ in the experimental TMR (1.73 Mcal) vs. the control TMR (1.66 Mcal) and by higher in vitro OM and NDF digestibilities of the experimental diet (77.7 and 59.8\%, respectively; Table 1) vs. the control TMR (73.0 and 44.4\%, respectively). This difference also affected feeding behavior and milk performance, as shown subsequently.

\section{Feeding Behavior}

Feeding behavior data of 11,000 visits of the cows in their individual feeding lot were analyzed, and average 
Table 2. Feeding behavior and daily intake of cows fed the 2 TMR.

\begin{tabular}{lcccc}
\hline Variable & Experiment $^{1}$ & Control $^{1}$ & SEM & $P$ \\
\hline Meals per day & $16.6^{\mathrm{a}}$ & $21.0^{\mathrm{b}}$ & 0.28 & 0.05 \\
Meal duration (min per meal) & $12.1^{\mathrm{a}}$ & $9.47^{\mathrm{b}}$ & 0.08 & 0.02 \\
Eating duration (min/d) & 201 & 199 & 4.32 & 0.44 \\
Eating duration (min/kg of NDF) & $20.7^{\mathrm{a}}$ & $21.6^{\mathrm{b}}$ & 0.24 & 0.05 \\
Meal intake (DM; kg per meal) & $1.51^{\mathrm{a}}$ & $1.22^{\mathrm{b}}$ & 0.02 & 0.03 \\
Rate of meal intake (DM; g/min) & 125 & 129 & 22 & 0.11 \\
Daily DMI (kg/d) & 25.0 & 25.7 & 0.82 & 0.23 \\
Daily NDF intake (kg/d) & $9.73^{\mathrm{a}}$ & $9.23^{\mathrm{b}}$ & 0.13 & 0.05 \\
Predicted DMI $^{2}$ (kg/d) & 24.0 & 23.3 & 0.70 & 0.25 \\
\hline
\end{tabular}

\footnotetext{
${ }^{\mathrm{a}, \mathrm{b}}$ Means in the same row followed by different superscripts differ at $P<0.05$.

${ }^{1}$ Experiment $=$ TMR containing $12 \% \mathrm{NDF}$ of roughage origin; control $=$ TMR containing $18 \% \mathrm{NDF}$ of forage origin.

${ }^{2}$ Predicted DMI was calculated according to NRC (2001) based on individual 4\% FCM production, BW, and days in milking of the cows in both groups.
}

results are summarized in Table 2 and Figures 1 to 3 . Figure 2 and Table 2 show that, in the control group, about $80 \%$ of meals were $<15$ min with an average of $9.47 \mathrm{~min}$ per meal; in the experimental group, about $30 \%$ of the meals lasted $>15$ min with significantly higher meal duration (12.1 min per meal). The eating speed of the 2 TMR during each meal was about the same (125 to $129 \mathrm{~g} / \mathrm{min}$; Table 2 ), and it probably reflects the similar density of the 2 TMR (Table 1 ). As a result, in each meal, cows on the experimental TMR ate significantly more DM than did those on the control TMR (1.51 and $1.22 \mathrm{~kg}$ of DM per meal, respectively; Table 2 ), and about $90 \%$ of the meals of the experimental group ended with consumption of up to $5.5 \mathrm{~kg}$ of wet food per meal compared with $4.5 \mathrm{~kg}$ of wet food per meal in the control group (Figure 2). Possible explanations to

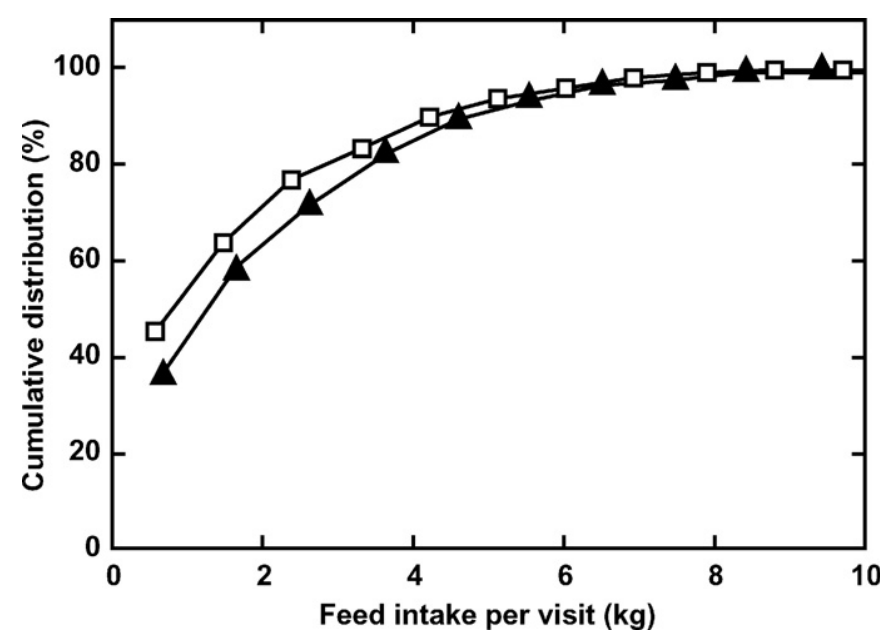

Figure 1. Consumption behavior, feed intake $(\mathrm{kg})$ per meal, in the experimental $(\mathbf{\square})$ and control $(\boldsymbol{\Lambda})$ groups. $\mathrm{n}=11,100$ meals. A meal is defined as a visit to the feeding lane, consumption of $>0.1$ $\mathrm{kg}$, and a duration of $>5 \mathrm{~s}$. the difference between dietary treatments in size and duration of individual meals include the following. 1) The advantage of the experimental TMR in extent of $\mathrm{OM}$ and $\mathrm{NDF}$ digestibility and $\mathrm{NE}_{\mathrm{L}}$ content (Table 2) may cause the cows to reach a short-term full-stomach feeling more slowly (Allen, 1996). 2) The experimental TMR is probably more tasty to the cows and, therefore, is consumed more willingly than the control TMR. The inclusion of more oat hay in the experimental diet compensated for the lower content of roughage NDF and was reflected in similar fiber effectiveness in both TMR as measured by density ( $0.48 \mathrm{~kg} / \mathrm{L}$ in both TMR).

Cows fed the control TMR ate significantly more meals per day than the experimental group (21.0 vs. 16.6 meals/d, $P<0.05$; Table 2 and Figure 3 ). A possible explanation for this finding is that the higher extent of

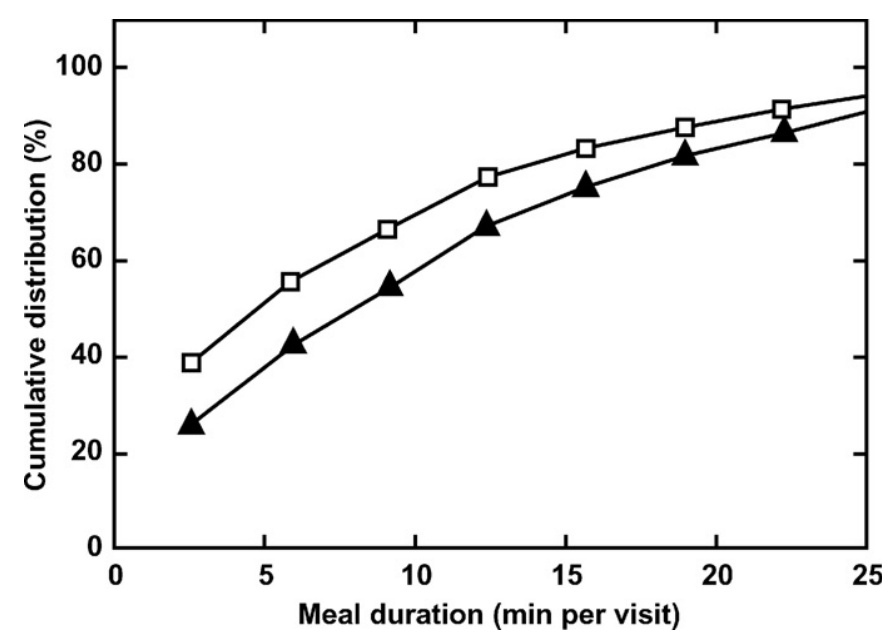

Figure 2. Consumption behavior, meal duration (min) in the experimental $(\mathbf{\square})$ and control $(\boldsymbol{\Delta})$ groups; $\mathrm{n}=11,100$ visits. A meal is defined as a visit to the feeding lane, consumption of $>0.1 \mathrm{~kg}$, and a duration of $>5 \mathrm{~s}$. 


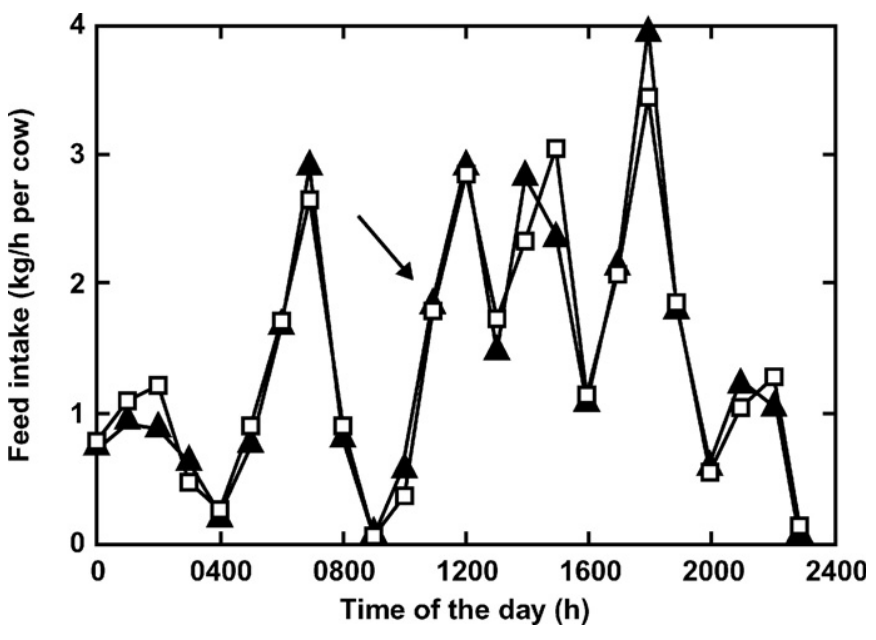

Figure 3. Diurnal pattern, feed intake $(\mathrm{kg} / \mathrm{h})$ per cow in the experimental ( $\mathbf{\square})$ and control ( $\mathbf{\Delta})$ groups throughout an average day. The arrow indicates dispensing time of a fresh TMR. The other peaks are the timing of cow return from milking or cooling showers.

DMI per meal (Table 2) and OM digestibility of the experimental TMR (Table 1) may supply the blood of cows more metabolites that may further reduce hunger feeling and inhibit short-term cow appetite, increase the interval between meals, and reduce the number of meals per day as shown also in the study of Friggens et al. (1998), who replaced roughage with concentrates.

This advantage of the control group in number of meals per day compensated for the advantage of the experimental group in average meal size and duration; therefore, the accumulated daily eating duration of the 2 TMR was similar (199 to $201 \mathrm{~min} / \mathrm{d}$ ) as well as their total daily DMI (25.0 to $25.7 \mathrm{~kg}$; Table 2). Notwithstanding, the average eating duration of dietary NDF was significantly longer in the control group as compared with the experimental cows ( $21.6 \mathrm{vs} .20 .7 \mathrm{~m} / \mathrm{kg}$ of NDF ingested). Support for these findings is given from previous studies showing that replacement of 15 to $23 \%$ of roughage with $\mathrm{SH}$ did not affect daily $\mathrm{DM}$ eating duration but significantly reduced eating duration per kilogram of NDF ingested (Weidner and Grant, 1994; Slater et al., 2000). The similarity in eating duration of the 2 TMR of this study is in contrast to the data reported by Friggens et al. (1998), who found that replacement of roughage by starchy grains reduced DM eating duration from about $200 \mathrm{~m} / \mathrm{d}$ (as in our study) to $160 \mathrm{~m} / \mathrm{d}$. Therefore, it is suggested that mode and rate of $\mathrm{SH}$ ingestion differ from that of starchy grains.

\section{Distribution of Feeding During the Day}

Although the feed intake per meal and meal duration differed significantly between the control and experi- mental groups (Figures 1 and 2; Table 2), the distributions of the feeding times during the day and night were not significantly different (Figure 3). Figure 3 shows that, in both groups, most of the food (77\%) was consumed during day hours between 0500 and $2000 \mathrm{~h}$, and only $23 \%$ of total daily intake was recorded between the night and morning milking. The distribution of feeding throughout the day was dominated by management practices, including return from milking $(0600,1400$, and $2100 \mathrm{~h}$ ) or cooling showers (1200 and $1600 \mathrm{~h})$ and the dispensing time of basic TMR - $1000 \mathrm{~h}$, as reflected by the picks of meals shown in Figure 3. The extra meals of the control group occurred generally at the pick times of feeding and milking mentioned previously (Figure 3). This picture is of special importance in view of the heat load data shown in Figure 4. One would expect the cows in both groups to avoid visiting the feeding lane during the hottest hours of the day (Figure 4). However, although ambient temperature reached the upper level of $30^{\circ} \mathrm{C}$ with high level of global radiation between 1000 to $1600 \mathrm{~h}$ (Figure 4), it hardly affected the peaks of feed intake shown in Figure 3, probably because of the 2 showers applied to cool the cows at 1200 and $1600 \mathrm{~h}$. However, the results for the entire period of the experiment showed that the cows responded to both the management routine and heat load effects: eating followed feed dispensing, showers, and milking, and the eating peak that followed the midday milking was succeeded, in both groups, by a fall to almost zero feeding for about $2 \mathrm{~h}$. The tendency to avoid feeding in the hot hours can be recognized in 2 findings: 1) the decline in feeding visits and consumption 1 to 2 $\mathrm{h}$ after food distribution and 2) the high proportion of the feeding visits and feed consumption that took place between $1700 \mathrm{~h}$ and the night milking and the relatively active feeding behavior after the night milking.

This result is in contrast to the study of Halachmi (1999), who found that, in a robotic milking situation, the cows eventually balanced their meals throughout day and night almost equally over the $24 \mathrm{~h}$. The conflict between studies can be explained by the different triggers that motivated cows to approach the feeding lane. In the present study, the triggers were external stimulating events including feeding, showers, and return from milking together with social stimulation of other cows as demonstrated by Metz and Mekking (1978), whereas in the study of Halachmi et al. (1999), the predominant triggers were restriction parameters dictated by the milking robot.

In previous studies (Uetake et al., 1997; Halachmi, 2000; Halachmi et al., 2000a), management practices such as feed dispensing frequency were found to have critical influence on the cows' feeding behavior. The present results support this finding: the distribution of 

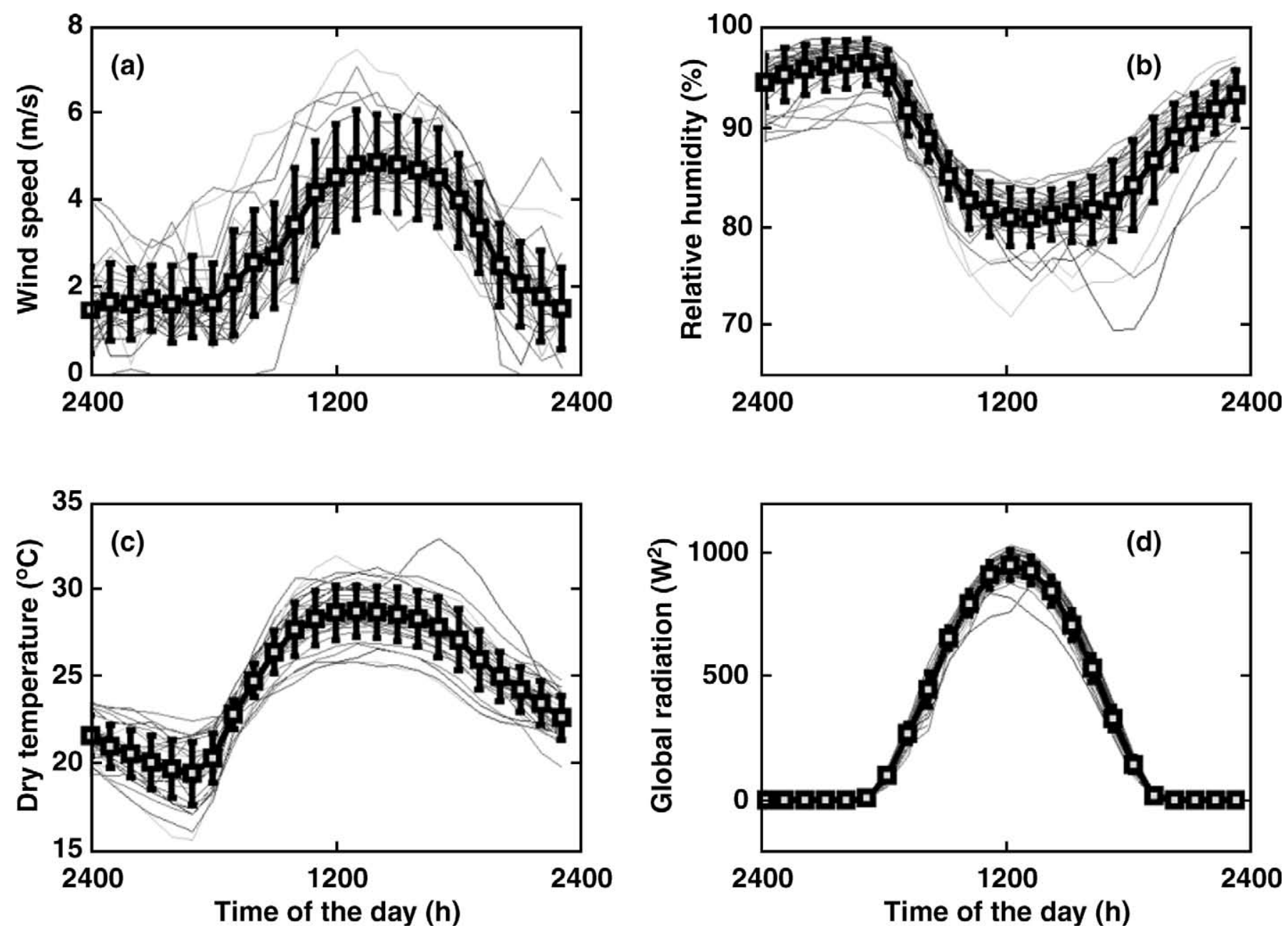

Figure 4. Heat load during the experimental period: wind speed (a), relative humidity (b), dry temperature (c), and global radiation (d). Each day is one single line; average values of all experimental days are displayed as a line of boxes. The 'whiskers' are the lines extending from each end of the box to show the extent of the standard deviation.

the feeding times during the day and night did not differ significantly between the different TMR (Figure 3 ), and it could be that the identical management regimes (both control and experiment cows held in one single group) exerted a dominant influence over the differences in feed palatability and digestibility. Thus, management practices should be taken into account in every mathematical and simulation model intended to predict feed consumption.

Our behavior results are in contrast with those reported by Morita et al. (1996), who studied the effect of concentrate feeding on subsequent roughage intake and found lower feeding stall visits (8.4 visits/d), higher meal duration (18.9 min per meal), and higher average rate of meal consumption than found in our study (Figure 2). This contrast reflects the difference between studies in diet composition and management practices.

\section{Prediction of DMI}

The daily intakes of DM and NDF are summarized in Table 2. Average daily DMI per cow was similar in the experimental and control groups (25.0 and $25.7 \mathrm{~kg} /$ $\mathrm{d}$, respectively); however, average NDF intake was significantly higher in the experimental group (9.73 vs. $9.23 \mathrm{~kg} / \mathrm{d}$ ). This result reflects the feeding behavior picture and NDF digestibility differences discussed previously.

Measuring individual feeding behavior of high-producing cows fed 2 diets differing in source and digestibility of NDF provides an opportunity to evaluate the NRC model for predicting DMI of cows based only on their milk and 4\% FCM yields, days in milking, and BW data, while avoiding considerations of diet composition (NRC, 2001). Table 2 shows the predicted average DMI 
Table 3. Performance of cows fed the 2 TMR.

\begin{tabular}{|c|c|c|c|c|}
\hline Variable & Experiment $^{1}$ & Control $^{1}$ & SEM & $P$ \\
\hline Milk yield (kg/d) & $38.5^{\mathrm{a}}$ & $36.3^{\mathrm{b}}$ & 0.48 & 0.05 \\
\hline Milk fat (\%) & 3.40 & 3.39 & 0.09 & 0.41 \\
\hline Milk protein (\%) & 3.04 & 3.08 & 0.06 & 0.27 \\
\hline Milk lactose (\%) & 4.75 & 4.68 & 0.04 & 0.17 \\
\hline Milk fat $(\mathrm{kg} / \mathrm{d})$ & $1.31^{\mathrm{a}}$ & $1.23^{\mathrm{b}}$ & 0.02 & 0.05 \\
\hline Milk protein $(\mathrm{kg} / \mathrm{d})$ & $1.17^{\mathrm{a}}$ & $1.12^{\mathrm{b}}$ & 0.02 & 0.11 \\
\hline $4 \%$ FCM yield $(\mathrm{kg} / \mathrm{d})$ & $35.0^{\mathrm{a}}$ & $33.0^{\mathrm{b}}$ & 0.41 & 0.04 \\
\hline $\mathrm{ECM}^{2}$ yield $(\mathrm{kg} / \mathrm{d})$ & $41.1^{\mathrm{a}}$ & $39.3^{\mathrm{b}}$ & 0.56 & 0.05 \\
\hline BW (kg per cow) & 605 & 603 & 8.77 & 0.47 \\
\hline
\end{tabular}

of cows fed the 2 dietary treatments calculated for each cow according to the model of NRC (2001) in comparison with the actual DMI measured in this study. Data show that the NRC model predicted 4 and 9.3\% lower DMI for the experimental and control cows (predicted DMI of 24.0 and $23.3 \mathrm{~kg} / \mathrm{d}$ vs. actual DMI of 25.0 and 25.7 $\mathrm{kg} / \mathrm{d}$, respectively). The higher gap in prediction of DMI of the control group can be explained by the lower $\mathrm{NE}_{\mathrm{L}}$ content of this ration $(1.66 \mathrm{Mcal} / \mathrm{kg}$ of $\mathrm{DM})$ as compared with the average $\mathrm{NE}_{\mathrm{L}}$ content $(1.72 \mathrm{Mcal} / \mathrm{kg}$ of $\mathrm{DM})$ used in NRC (2001) model. However, previous studies have demonstrated that when roughage or starchy grains are replaced by non-roughage highly digestible NDF-rich by-products such as SH, prediction of DMI may be underestimated, and other models that take into account management practices are probably preferred (Halachmi, 2000; Halachmi et al., 2001; Miron et al., 2003; Halachmi et al., 2004).

\section{Milk Yield and Composition}

Performance data of the cows fed the 2 TMR is shown in Table 3. As a result of the differences between the dietary treatments, the average milk yields of the experimental cows tended to be higher than those of the control group ( 38.5 and $36.3 \mathrm{~kg} / \mathrm{d}$, respectively, $P \leq 0.05$ ). The average concentrations of milk fat and milk protein were similar in the 2 groups; however, the production of milk fat, $4 \% \mathrm{FCM}$, and ECM were significantly higher $(P \leq 0.05)$ in the experimental group than in the control group. This result might be due to the higher NDF intake and higher $\mathrm{NE}_{\mathrm{L}}$ and in vitro digestibility of the $\mathrm{OM}$ and NDF in the experimental ration as compared with the control TMR. Because a no-starch ingredient (SH) was used to replace a starch-containing material (CS), it is possible that ruminal environment was more favorable for fermentation and microbial protein synthesis and that this was reflected in improved digestion and performance. Enhanced digestibility of NDF polysaccharides usually results in increased production of acetate by rumen cellulolytic bacteria (Chesson and Forsberg, 1997), and this can serve as a precursor for milk fat synthesis in the mammary gland.

Support for these performance data is given in our previous study, which used similar rations under moderated weather conditions (Miron et al., 2003), and in other studies showing that replacement of roughage with $\mathrm{SH}$ (14 to $25 \%$ of dietary DM) tended to increase milk and $4 \%$ FCM production by lactating cows (Slater et al., 2000; Ipharraguerre and Clark, 2003).

\section{Modeling Possibilities}

For practical purposes, such as the application of simulation to farm design, it is important to be able to predict the total time spent in eating according to the amount of feed dispensed in the feeding lane and management practices (Halachmi et al., 2000a,b, 2002, 2003). A simple regression model leads to a value of $\mathrm{R}^{2}=0.98$ (with regression coefficients, $\mathrm{B}=[4.47,0.42]$

Table 4. Modeling eating time derived from feed quantity.

\begin{tabular}{llrll}
\hline & Coefficients & & $\mathrm{R}^{2}$ & $\mathrm{P}$ after switching \\
\hline Experiment & 4.47 & 0.42 & 0.981 & 0.018 \\
Control & 4.53 & -0.30 & 0.986 & 0.026 \\
\hline
\end{tabular}

\footnotetext{
${ }^{1}$ Model-sensitive analysis; switching the regression coefficients obtained for the control TMR with the regression coefficient obtained in the experimental TMR.
} 
and $[4.53,-0.30]$ in the experimental and control groups, respectively; Table 4. Switching the regression coefficients obtained for one TMR with those obtained for the second TMR does not severely damage the model, which suggests that modeling the dependence of the time spent eating on the amount of feed supplied is not very sensitive to feed compositions. However, this hypothesis should be rechecked in further research with a completely different type of feed, different climate, and different cows (Friggens et al., 1998). Simulation models also take management practices into account (Halachmi, 2000); therefore, they could be more accurate than a simple regression model or a mathematical model (Mertens, 1987, 1997) that hardly includes management practices. For validation of a simulation model that includes management practices, see Halachmi et al. (2001).

The very wide variations in consumption rate in the course of the day (Figure 3) occurred mainly near milking and feeding times as well as times when the heat stress had passed its peak, which suggests that an attempt to model feed consumption without taking the management-controlled parameters (feeding and milking times) into account would be liable to yield misleading results. Halachmi (2000) reached the same conclusion, although he based it on cows milked by a robot (automatic milking).

\section{CONCLUSIONS}

The experimental TMR was more digestible in vitro than the control TMR, and this affected feeding behavior, as cows that received the experimental TMR stayed longer in the feeding lane and ate more TMR in each meal but in fewer meals as compared with cows that received the control TMR. As a result, the experimental group ate similar DM per day but ate more digestible $\mathrm{NDF}$ and produced more milk and $4 \%$ FCM than the control group. Therefore, we concluded that, under hot climatic conditions (Israel in June), it is feasible to replace CS with SH. If the management practices such as milking frequency, feeding times, and amount of feed dispensed in the feeding lane are taken into account, it is practicable to model the cows' feeding behavior, including the time they spend eating.

\section{ACKNOWLEDGMENTS}

The authors acknowledge the assistance given by the farm staff at the Bet Dagan dairy barn, Agricultural Research Organization, Israel. Special thanks are due to S. Yakobi, M. Nikbachat, H. Lerer, and Y. Brender.

\section{REFERENCES}

Allen, M. S. 1996. Physical constraints on voluntary intake of forages by ruminates. J. Anim. Sci. 74:3063-3075.

Association of Official Analytical Chemists. 1984. Official Methods of Analysis. 14th ed. AOAC, Washington, DC.

Chesson, A., and C. W. Forsberg. 1997. Polysaccharides degradation by rumen microorganisms. Pages 329-381 in The Rumen Microbial Ecosystem. 2nd ed. P. N. Hobson and C. S. Stewart, ed. Blackie Academic and Professional, London, United Kingdom.

Cunningham, K. D., M. J. Cecava, and T. R. Johnson. 1993. Nutrient digestion, nitrogen and amino acid flows in lactating cows fed soybean hulls in place of forage or concentrate. J. Dairy Sci. 76:3523-3535.

Eastridge, M. L., H. F. Bucholtz, A. L. Slater, and C. S. Hall. 1998. Nutrient requirements for dairy cattle of the national research council versus some commonly used software. J. Dairy Sci. 81:3049-3062.

Firkins, J. L., and M. L. Eastridge. 1992. Replacement of forage or concentrate with combinations of soyhulls, sodium bicarbonate, or fat for lactating dairy cows. J. Dairy Sci. 75:2752-2760.

Friggens, N. C., B. Nielsen, I. Kyriazakis, B. J. Tolkamp, and G. C. Emmans. 1998. Effects of feed composition and stage of lactation on the short-term feeding behavior of dairy cows. J. Dairy Sci. 81:3268-3277.

Halachmi, I. 1999. Designing methodology for the robotic milking barn: Modelling, simulation, validation and optimization. Ph.D. Thesis. Wageningen University, The Netherlands.

Halachmi, I. 2000. Designing the optimal robotic barn, Part 2: Behavior-based simulation. J. Agric. Eng. Res. 77:67-79.

Halachmi, I., Y. Edan, E. Maltz, U. M. Peiper, I. Brukental, and U. Moalem. 1998. A real-time control system for individual dairy cow food intake. Comp. Electr. Agric. 20:131-144.

Halachmi, I., I. J. B. F. Adan, J. van der Wal, J. A. P. Heesterbeek, and P. van Beek. 2000a. The design of robotic dairy barns using closed queuing networks. Eur. J. Oper. Res. 124:437-446.

Halachmi, I., J. H. M. Metz, E. Maltz, A. A. Dijkhuizen, and L. Speelman. 2000b. Designing the optimal robotic barn, Part 1: Quantifying facility usage. J. Agric. Eng. Res. 76:37-49.

Halachmi, I., A. Dzidic, J. H. M. Metz, L. Speelman, A. A. Dijkhuizen, and J. P. C. Kleijnen. 2001. Validation of simulation model for robotic milking barn design: Case study. Eur. J. Oper. Res. 134:165-176.

Halachmi, I., J. H. M. Metz, A. van't Land, S. Halachmi, and J. P. C. Kleijnen. 2002. Optimal facility allocation in a robotic milking barn. Trans. ASAE 45:1539-1546.

Halachmi, I., J. A. P. Heesterbeek, I. J. B. F. Adan, J. van der Wal, and P. van Beek. 2003. Designing the optimal robotic barn, using queuing network model. Agric. Syst. 76:681-696.

Halachmi, I., Y. Edan, U. Moallem, and E. Maltz. 2004. Predicting feed intake of the individual dairy cow. J. Dairy Sci. 87:22542267.

Ipharraguerre, I. R., and J. H. Clark. 2003. Soyhulls as alternative feed for lactating cows. J. Dairy Sci. 86:1052-1073.

Little, T. M., and F. J. Hills. 1978. Agricultural Experimental Design and Analysis. John Wiley and Sons, New York, NY.

Mertens, D. R. 1987. Predicting intake and digestibility using mathematical models of ruminal function. J. Anim. Sci. 64:1548-1558.

Mertens, D. R. 1997. Creating a system for meeting the fiber requirements of dairy cows. J. Dairy Sci. 80:1463-1481.

Metz, J. H. M., and P. Mekking. 1978. Adaptation in the feeding pattern of cattle according to the social environment. Pages 2426 in Proc. Zodiac Symp. Adaptation, The Wageningen Press, Wageningen, The Netherlands.

Miron, J., E. Yosef, and D. Ben-Ghedalia. 2001. Composition and in vitro digestibility of monosaccharide constituents of selected byproduct feeds. J. Agric. Food Chem. 49:2322-2326.

Miron, J., E. Yosef, E. Maltz, and I. Halachmi. 2003. Soybean hulls as a replacement of forage neutral detergent fiber in total mixed rations of dairy cows. Anim. Feed Sci. Technol. 106:21-28.

Morita, S., S. Devir, C. C. Ketelaar-de lauwere, A. C. Smits, H. Hogeveen, and J. H. M. Metz. 1996. Effects of concentrate intake on subsequent roughage intake and eating behavior of cows in an automatic milking system. J. Dairy Sci. 79:1572-1580. 
Mowrey, A., M. R. Ellersieck, and J. N. Spain. 1999. Effect of fibrous by-products on production and ruminal fermentation in lactating dairy cows. J. Dairy Sci. 82:2709-2715.

National Research Council. 2001. Nutrient Requirements of Dairy Cattle. 7th rev. ed. Natl. Acad. Sci., Washington, DC.

SAS User's Guide: Statistics, Version 6.12 Edition. 1996. SAS Inst., Inc. Cary, NC.

Slater, A. L., M. L. Eastridge, J. L. Firkins, and L. J. Bidinger. 2000. Effects of starch source and level of forage neutral detergent fiber on performance of dairy cows. J. Dairy Sci. 83:313-321.
Tilley, J. M., and R. M. Terry. 1963. A two stage technique for the in vitro digestion of forage crops. J. Br. Grassland Soc. 18:104-111.

Uetake, K., J. F. Hurnik, and L. Johnson. 1997. Behavioral pattern of dairy cows milked in a two-stall automatic milking system with a holding area. J. Anim. Sci. 75:954-958.

van Soest, P. J., J. B. Robertson, and B. A. Lewis. 1991. Methods for dietary fiber, neutral detergent fiber, and non-starch polysaccharides in relation to animal nutrition. J. Dairy Sci. 74:3583-3597.

Weidner, S. J., and R. J. Grant. 1994. Soyhulls as a replacer for forage fiber in diets for lactating dairy cows. J. Dairy Sci. 77:513-521. 